\title{
Multi-methodical realisation of Austrian climate maps for 1971-2000
}

\author{
J. Hiebl, S. Reisenhofer, I. Auer, R. Böhm, and W. Schöner \\ Central Institute for Meteorology and Geodynamics, Vienna, Austria
}

Received: 9 September 2010 - Revised: 14 December 2010 - Accepted: 27 January 2011 - Published: 5 February 2011

\begin{abstract}
Constantly changing climate, the availability of a higher resolved digital elevation model and further development of geostatistical interpolation methods gave reason for updating the most frequently demanded climate maps out of the Austrian digital climate atlas from 1961-1990 to 1971-2000. To achieve a station density as high as possible, data from eleven national and foreign institutes were collected and gapfilled. According to the climate parameter, different geostatistical interpolation methods (including regionalised multilinear regressions, geographically weighted regressions and curve fitting to base parameter) were applied. The resultant 17 grids concern 30-year-means of air temperature, precipitation and snow parameters as well as derived indices. They are now available for a variety of scientific and planning purposes.
\end{abstract}

\section{Introduction}

The construction of DEMs (digital elevation models) together with the launch of more and more powerful GIS (geographical information system) software products prompted the rapid development of sophisticated geostatistical interpolation methods in climatology since the late 1980s (e.g. Bénichou and LeBreton, 1987; Daly et al., 1994; Hutchinson, 1995; cf. Dobesch et al., 2007; Carrega, 2010). The advantage of these methods is obvious: the resultant areal raster fields contain information for a number of points, which is of several orders of magnitude larger than the number of ingoing meteorological stations, allowing applications in a wide range of fields such as climate (impact) research, all other branches of geosciences, agriculture and forestry, engineering, water management, tourism and natural resource conservation.

Consequently, nearly all national meteorological services established digital maps of standard normal values (e.g. Cegnar, 1995; DWD, 1999; Zaninović et al., 2008). For Austria, Auer et al. (2001) at the Central Institute for Meteorology and Geodynamics (ZAMG) provided a multimedia climate atlas (ÖKLIM) including, among other things, 35 digital maps for the period 1961-1990. The 17 most frequently applied maps thereof have now been adapted and updated to the more recent period 1971-2000 (Table 1). This has been

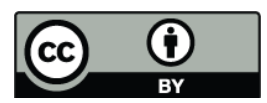

Correspondence to: J. Hiebl

(johann.hiebl@zamg.ac.at) done for several reasons: (1) Ongoing climate change - only the ten-years-shift in the reference period causes a rise of mean annual temperature of $0.3-0.4^{\circ} \mathrm{C}$ - made the former maps inappropriate for the analysis of current climate conditions, e.g. considering risk of frost, heating demand or snow cover duration. (2) In the meantime, a spatially higher resolved DEM for Austria has been introduced. (3) Above all, the updating of the digital maps permitted to stay abreast of the methodical developments in geostatistical interpolation during the last years.

\section{Data}

The quality of any interpolation result is limited by the quality of the underlying observational data. Therefore, two goals were set for data collection and preparation: not to confine to the national borders (unlike the first ÖKLIM project) and to achieve a spatial station density as high as possible.

Internationally arranged initiatives (e.g. Hiebl et al., 2009; Klein and Persson, 2009) have shown that the quality of national grids in border-near regions considerably depends on the availability of foreign station data. Especially in meridionally narrow Western Austria (where e.g. strong horizontal precipitation gradients are noted), knowledge of climate measurements from outside the borders is of use. In order to maintain a homogeneous level of validity across all parts of Austria, the study region for interpolation was extended to $45.5-50^{\circ} \mathrm{N}$ and $8.5-18^{\circ} \mathrm{E}$ (Fig. 1). For this domain, data were requested and kindly provided from almost 
Table 1. The final data collection according to climate parameter, country of origin and data provider. Bold station numbers denote gap-filling in the respective subdataset.

\begin{tabular}{|c|c|c|c|c|c|c|c|c|c|c|c|c|c|c|}
\hline & Country & int. & AT & AT & $\mathrm{DE}$ & $\mathrm{CZ}$ & SK & $\mathrm{HU}$ & HR & SI & IT & IT & $\mathrm{CH}$ & \\
\hline $\begin{array}{l}\text { Para- } \\
\text { meter }\end{array}$ & Institute & $\begin{array}{c}\text { ZAMG } \\
\text { (HISTALP) }\end{array}$ & ZAMG & HZB & DWD & CHMI & SHMU & OMSZ & DHMZ & ARSO & $\begin{array}{l}\text { OSMER- } \\
\text { ARPA }\end{array}$ & $\begin{array}{c}\text { Hydr. Office, } \\
\text { South Tyrol }\end{array}$ & $\begin{array}{l}\text { Meteo } \\
\text { Swiss }\end{array}$ & Total \\
\hline 1 & Air temperature, year & 96 & 153 & 232 & 100 & 147 & 7 & 13 & 28 & 29 & 6 & 41 & 42 & 894 \\
\hline 2 & Air temperature, January & 96 & 153 & 232 & 100 & 147 & 7 & 14 & 28 & 29 & 6 & 41 & 42 & 895 \\
\hline 3 & Air temperature, July & 96 & 153 & 232 & 100 & 147 & 7 & 15 & 28 & 29 & 6 & 41 & 42 & 896 \\
\hline 4 & Ice days, year & - & 207 & - & 100 & 148 & - & 15 & 8 & 32 & 6 & 44 & 46 & 606 \\
\hline 5 & Frost days, year & - & 207 & - & 100 & 148 & - & 15 & 27 & 32 & 6 & 44 & 45 & 624 \\
\hline 6 & Freeze-thaw days, year & - & 207 & - & 100 & 148 & - & 15 & 8 & 32 & 6 & 44 & 45 & 605 \\
\hline 7 & Summer days, year & - & 207 & - & 100 & 148 & - & 15 & 27 & 32 & 6 & 44 & 45 & 624 \\
\hline 8 & Hot days, year & - & 207 & - & 100 & 148 & - & 15 & 8 & 32 & 6 & 44 & 45 & 605 \\
\hline 9 & Heating degree days, year & - & 200 & - & 8 & 148 & - & - & - & - & 6 & 44 & 23 & 429 \\
\hline 10 & Precipitation sum, year & 89 & 133 & 623 & 98 & 147 & - & 11 & 25 & 28 & 11 & 53 & 181 & 1399 \\
\hline 11 & Precipitation sum, winter half-year & 90 & 134 & 580 & 98 & 147 & - & 11 & 25 & 28 & 11 & 53 & 181 & 1358 \\
\hline 12 & Precipitation sum, summer half-year & 91 & 135 & 581 & 98 & 147 & - & 11 & 25 & 28 & 11 & 53 & 181 & 1361 \\
\hline 13 & Days with precipitation, year & - & 164 & 500 & 107 & 148 & - & 16 & 12 & 32 & 11 & 56 & 191 & 1237 \\
\hline 14 & Solid precipitation, year & - & 155 & - & - & 148 & - & 16 & - & - & - & - & - & 319 \\
\hline 15 & Sum of fresh-fallen snow & - & 141 & 483 & 107 & 148 & - & - & 8 & - & - & - & 38 & 925 \\
\hline 16 & Snow cover duration & - & 147 & 479 & - & 148 & - & 16 & 15 & 32 & - & - & 25 & 862 \\
\hline 17 & Maximum snow depth & - & 147 & 504 & - & 148 & - & 16 & 7 & - & - & - & 34 & 856 \\
\hline
\end{tabular}

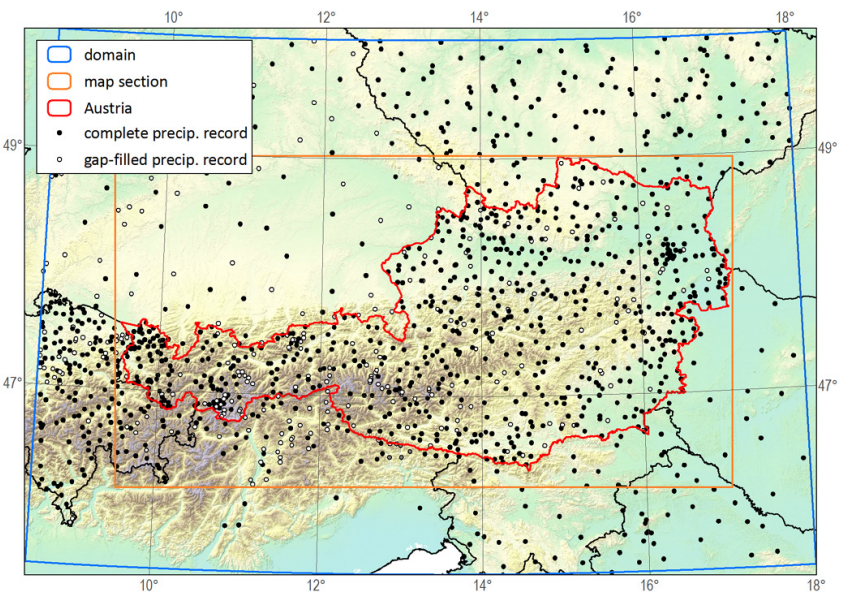

Figure 1. Location of the domain (for data collection and interpolation) and the map section (for printed products) in relation to the Austrian national borders (for digital products). In addition, the most extensive network of stations with means of annual precipitation sum is depicted.

all neighbouring countries and Croatia. In cases when, besides the national record version, a homogenised record version out of the HISTALP (historical instrumental climatological surface time series of the greater Alpine region) project (Auer et al., 2007) was available, the latter was preferred. For instance, a network of nearly 900 stations could be utilised for air temperature and nearly 1400 stations for precipitation (Fig. 1, Table 1).

This data collection would not have been possible without extensive gap-filling. The challenge was to find a favourable compromise between the gain of spatial information by gapfilling and growing uncertainty by too long temporal gaps. The applied method of gap-closing was strongly depending on the considered parameter: For parameters with high spatial representation like air temperature a maximum gap of ten out of $30 \mathrm{yr}$ was set. For precipitation and snow parameters, however, only five missing years were allowed because of their lower spatial transferability.

Gaps in air temperature, precipitation and snow records were closed relating to highly correlated, preferably homogenised (HISTALP), reference stations. Missing values in records of parameters derived from temperature or precipitation were filled by curve fitting to the base parameter at the very same station (mostly hyperbolic tangent or tangent thereof; Auer et al., 2005). In any case, even if the annual mean value of a parameter was to be mapped, gapfilling was performed on basis of the monthly series. This, together with the conservative choice of gap length, keeps the induced uncertainties low. Even though comprehensive validation of gap-filling was beyond the scope of the project, exemplary plausibility checks argue for the applied procedures. The gained results are, in any case, to be preferred to averaging over incomplete series or series concerning different periods, as misleadingly often practiced.

In case of air temperature data, inhomogeneities due to nationally different methods of the estimation of daily means were finally corrected, relying on existing adjustment factors used in Hiebl et al. (2009).

The DEM underlying all grid fields is provided by the Federal Office of Metrology and Surveying (BEV) in an original resolution of $50 \times 50 \mathrm{~m}$ with an estimated mean error between $\pm 1 \mathrm{~m}$ in agricultural and settlement area and $\pm 10 \mathrm{~m}$ in forested and high Alpine area (BEV, 2010). In order to increase usability and to achieve a maintainable spatial resolution, the DEM has been transferred into geographic coordinates featuring a cell size of $9.65^{\prime \prime}$, corresponding to $200 \mathrm{~m}$ in the longitudinal and $300 \mathrm{~m}$ in the latitudinal direction. 


\section{Methods}

The choice of the geostatistical interpolation method most appropriate for a certain climate parameter requires knowledge about the parameter's physical background and climatological-spatial behaviour as well as about the method's functionality, strengths and shortcomings (cf. Dobesch et al., 2007). In the following sections, the applied procedures are subsumed to three groups.

\subsection{Regionalised multilinear regressions}

Three grid fields, those on annual air temperature and monthly air temperature in January and July, are based on regionalised multilinear regressions. In course of this method, multilinear regressions of air temperature against macroclimatic explanatory variables are calculated in several horizontal subregions and three vertical layers (Hiebl et al., 2009). The approach has been chosen because it is appropriate for spatially highly representative parameters with strong elevation dependency. Moreover, other (not auto-correlated) large-scale variables controlling the climate parameter can be considered and modifications in subregions (like valleys and basins prone to temperature inversions) can be incorporated. Generally, the highly transparent method is easily manageable.

High station density allowed for dividing the domain into 37 horizontal subregions of temperature climate corresponding to geographic entities such as forelands, valleys and basins. Such small-scale subregions better reflect the strong regional peculiarities of temperature climate in Alpine terrain and justify problems of smoothing at the subregions' borders. In addition, the vertical dimension was divided into three layers: (1) In the lower layer (extra-Alpine $<600 \mathrm{~m}$ to centralAlpine $<1800 \mathrm{~m}$ ), station data were analysed separately for each horizontal subregion by calculating multilinear regressions against elevation, (topographically weighted) distance from the coast, latitude and longitude in extra-Alpine forelands and basins. Simple linear regressions against elevation were calculated in inner-Alpine valleys and basins, where, accordingly to the smaller extension of the subregions, largescale dependencies are too weak. (2) In the upper layer (mostly $>1700 \mathrm{~m}$ to central-Alpine $>2300 \mathrm{~m}$ ), all stations were brought together to one single high-Alpine subregion to be processed in multilinear regression calculation. (3) In the intermediate layer, the temperature value for each grid point was averaged between the lower layer's upper level and the upper layer's lower level, weighted according to the grid point's elevation. This threefold layering facilitates the description of the, especially winterly, ground-level layer of reduced or even inverted temperature decrease with elevation. For the GIS-based creation of the raw temperature fields, raster grids of the regression coefficients were generated and smoothed at the subregions' borders. In a second step, mesoclimatological temperature modifications, namely

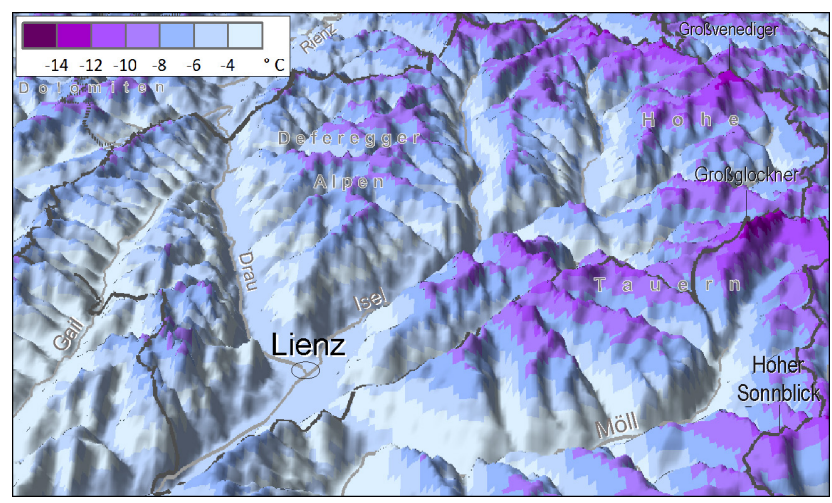

Figure 2. Map example 1. Mean monthly air temperature in January, bird eye's view on map section for East Tyrol (westward view, vertical exaggeration 2:1). Note the embedded effect of mesoclimate modification on slopes.

extra-Alpine inversions, lakeside effects, urban heat islands and slope effects were integrated following the tailored techniques described in detail in Hiebl et al. (2009) (Fig. 2).

\subsection{Geographically weighted regressions}

Six grid fields, those on annual, winter half-year and summer half-year precipitation sums as well as on sum of fresh-fallen snow, snow cover duration and maximum snow depth, rely on geographically weighted regressions. Such procedures have been introduced by Daly et al. (1994, 2008), applied by Frei and Schär (1998) and Schwarb (2000) in the Alpine region and adapted methodically for the present purpose. The method again strongly involves elevation dependencies but allows for a higher degree of spatial variability compared to the (regionalised) global regressions used for temperature interpolation, making it the better choice for the interpolation of precipitation sum and snow parameters in mountain regions. However, it is sensitive to sparse station coverage in high-elevation areas.

Applying geographically weighted regressions, an individual regression of the climate parameter against elevation was calculated at each grid point involving the closest stations. To control their contribution, the stations have been weighted according to their representativeness for the topographical conditions at the grid point. Checking different weights and parameterisations, the 15 nearest records were selected to be weighted by their horizontal distance and by their location north or south to the main Alpine crest. Because the method produces unrealistic gradients in regions with few high-elevation observations, several so-called control points were set. This was done by duplicating an observed value along a mountain range or by estimating an artificial value out of climatological experience. Even though this introduces a certain degree of subjectivity, it is inevitable in steep terrain with a systematic lack of sites at high altitudes. 


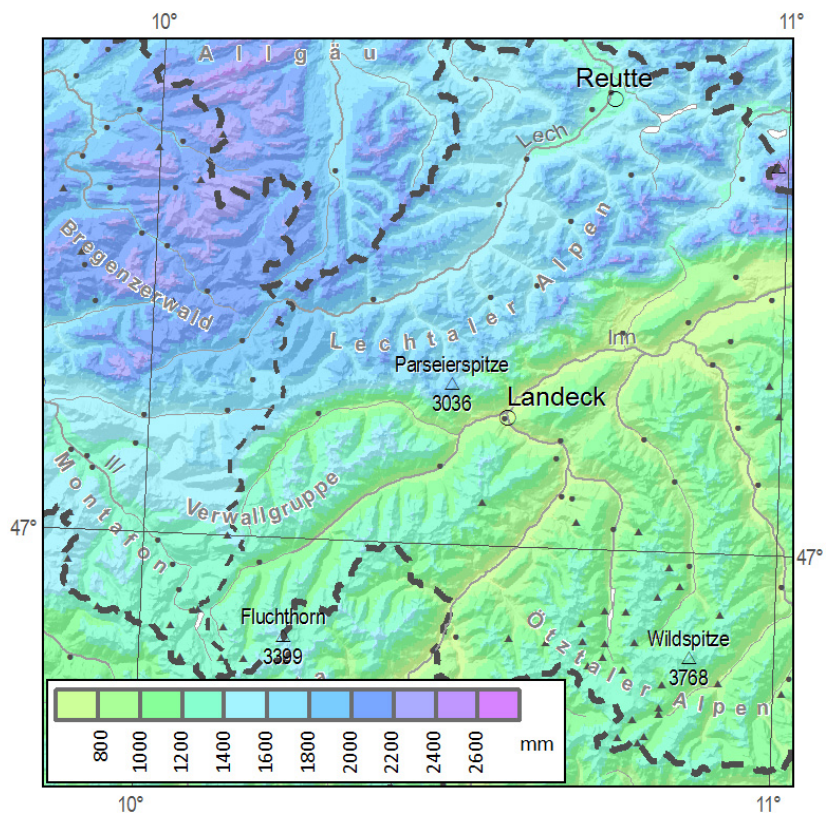

Figure 3. Map example 2. Mean annual precipitation sum, map section for a part of Western Austria.

Similarly, Peterson et al. (1998) emphasise the importance of the experienced climatologist's subjective judgement in addition to objectified methods in the editing of climate data (in a different context).

Like for air temperature, an effect of mesoscale climate was embedded into the precipitation fields. Böhm (1979) statistically proofed a precipitation increase triggered by higher concentration of condensation nuclei and thermal lift in the lee of Vienna. The then revealed pattern, expressed as a ready-to-use field of relative precipitation modification, was integrated into the precipitation fields. The final precipitation and snow fields realistically simulate the strong spatial variations such as abrupt transitions from Nordstau ranges to inner-Alpine dry valleys (e.g. from the Lechtal to the Ötztal Alps; Fig. 3).

\subsection{Curve fitting}

The remaining eight grid fields, all on secondary parameters of air temperature or precipitation climate, are based upon curve fitting to the primary parameters. On the one hand side, these indices are by definition, mostly by a threshold, directly derived from air temperature or precipitation sum. On the other hand side, the close climatic relations permit to attach the interpolation of the derived parameters to the already existing grids of the base parameters. This approach's clear advantage is due to the considerably more extensive observation networks of air temperature and precipitation compared to the derived parameters (Table 1), which allows their spatial description with higher accuracy (Fig. 4).
The different types of curve fitting used for modelling the spatial distributions of the indices are listed in Table 2. Annual air temperature gave better results explaining ice and frost days compared to January temperature, which seems reasonable for a country dominated by high-elevated areas. Because of the generally high correlations between primary and secondary parameters, further regionalisation was not necessary. An exception can be seen in terms of the remarkable dichotomy in the relation between the annual number of days with precipitation and the annual precipitation sum (Fig. 5). The suspicion of a climate-divide-effect was confirmed by data splitting along the main Alpine crest. Separate exponential fits formed the bases for interpolation in two regions, whereupon one-sided smoothing, from north to south, was performed along the region border.

Among the interpolation procedures, the grid field on freeze-thaw-days is the exceptional case, which has, accordingly to its definition, simply been constructed as the difference between the grids on frost and ice days.

To finalise the grids, the respective stations residuals were Kriging-interpolated and added whenever it explained a relevant fraction of the residuals. For example, residuals of air temperature did show distinct (even tough weak) spatial patterns of remaining variance, but residuals of precipitation sum or snow parameters did not.

\section{Evaluation and discussion}

Six common error measures have been calculated for the spatial analyses of all parameters to describe the differences (residuals) between "true", observed station data and simulated data at the station locations (Table 3). This has been done at two stages: (1) Simulated values as directly calculated by the model (regionalised multilinear regressions, geographically weighted regressions, curve fitting) were compared to measurements. This allows for estimating the applicability of the chosen interpolation approaches per se. (2) Simulated values as indicated on the grid fields were set in relation to the measured station values. By doing so, the quality of the final interpolation products is specified. This involves potentially higher errors due to deviations of the DEM from true station elevations as well as potentially lower errors due to, optionally, integrating mesoscale effects, smoothing at subregion borders or residual Kriging.

The spatial interpolations of the three mean air temperature grids are featured by negligible biases (mean errors). The regionalised multilinear regressions produce typical MAE (mean absolute error) values around $0.45^{\circ} \mathrm{C}$ and RMSE (root mean squared error) values around $0.57^{\circ} \mathrm{C}$. The error values are still somewhat lower on the final climate maps and benefit, aside from other things, from the coordinate correction that has been accomplished for temperature stations only (RMSE of differences between DEM and station elevations by $11 \mathrm{~m}$ ). 


\section{Sommertage $J a h r$}

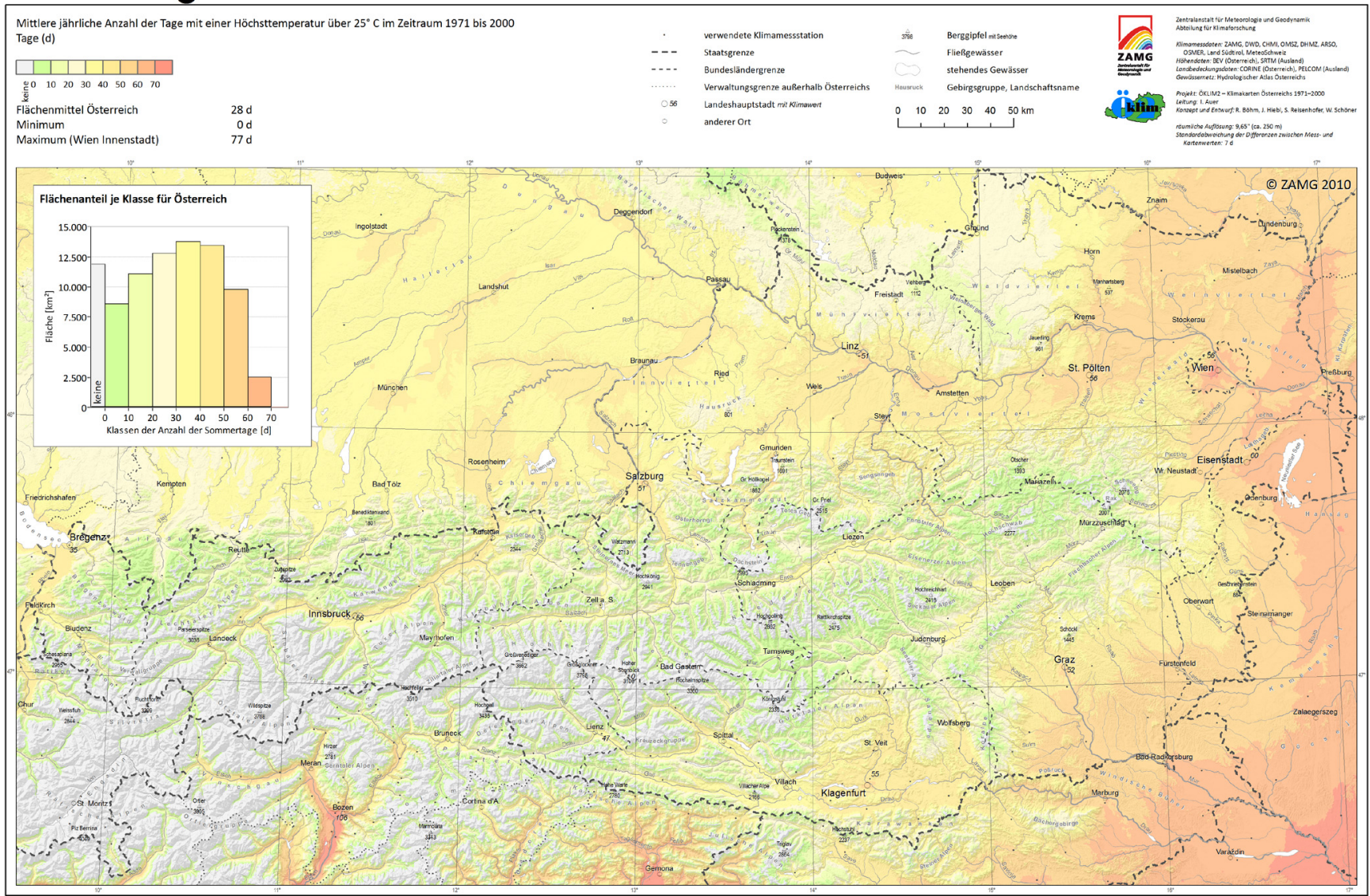

Figure 4. Map example 3. Mean annual number of days with a maximum temperature above $25^{\circ} \mathrm{C}$, entire map.

Table 2. Types of curve fitting of derived climate indices to primary parameters as basis for interpolation $\left(R^{2}-\right.$ coefficient of determination $)$.

\begin{tabular}{cllc}
\hline Parameter (cf. Table 1) & Independent variable & Type of function & $R^{2}$ \\
\hline 4 & Air temperature, year & Hyperbolic tangent & 0.99 \\
5 & Air temperature, year & Hyperbolic tangent & 0.98 \\
6 & - & - & - \\
7 & Air temperature, year & Linear regression & 0.76 \\
8 & Air temperature, year & Hyperbolic tangent & 0.73 \\
9 & Air temperature, year & Polynomial function & 0.99 \\
13 & Precipitation sum, year & Exponential function & 0.82 \\
14 & Air temperature, year & Hyperbolic tangent & 0.93 \\
\hline
\end{tabular}

Geographically weighted regressions applied on three precipitation sum and three snow parameter datasets give MRE (mean relative error) values of $0.8-3.1 \%$. The MARE (mean absolute relative error) and RMSRE (root mean squared relative error) values are lowest for precipitation sum of the summer half-year (5.9 and $8.1 \%$ respectively) and highest for the sum of fresh-fallen snow $(13.5 \%$ and $17.8 \%$ respectively). The final grid field errors are about the same size or slightly higher compared to the pure model errors, which can mainly be explained by larger elevation inconsistencies. Cross-validation proved the applicability of the method: If successively each observational value is left out once and used as validation data, the RMSRE would increase by only about $1.9 \%$ modelling fields of precipitation totals and by about $3.7 \%$ modelling fields of snow parameters. 
Table 3. Error measures (bias - mean error, MAE - mean absolute error, RMSE - root mean squared error, MRE - mean relative error, MARE - mean absolute relative error, RMSRE - root mean squared relative error) describing the deviations between observed values and simulated values as generated by the respective interpolation models (a) and as indicated on the final grid fields (b).

\begin{tabular}{|c|c|c|c|c|c|c|c|c|c|c|c|c|c|c|}
\hline \multirow{2}{*}{\multicolumn{2}{|c|}{$\begin{array}{l}\text { Parameter } \\
\text { (cf. Table 1) }\end{array}$}} & \multicolumn{6}{|c|}{ (a) Model } & \multicolumn{7}{|c|}{ (b) Grid field } \\
\hline & & \multirow{2}{*}{$\begin{array}{r}\text { Bias } \\
-0.04\end{array}$} & \multirow{2}{*}{$\begin{array}{r}\text { MAE } \\
0.40\end{array}$} & \multirow{2}{*}{$\begin{array}{r}\text { RMSE } \\
0.52\end{array}$} & \multirow{2}{*}{$\begin{array}{r}\text { MRE } \\
-\end{array}$} & \multirow{2}{*}{$\begin{array}{r}\text { MARE } \\
-\end{array}$} & \multirow{2}{*}{$\begin{array}{r}\text { RMSRE } \\
-\end{array}$} & \multirow{2}{*}{$\begin{array}{l}\text { Bias } \\
0.00\end{array}$} & \multirow{2}{*}{$\begin{array}{r}\text { MAE } \\
0.35\end{array}$} & \multirow{2}{*}{$\begin{array}{r}\text { RMSE } \\
0.45\end{array}$} & \multirow{2}{*}{$\begin{array}{r}\text { MRE } \\
-\end{array}$} & \multirow{2}{*}{$\begin{array}{r}\text { MARE } \\
-\end{array}$} & \multirow{2}{*}{$\begin{array}{r}\text { RMSRE } \\
-\end{array}$} & \multirow{2}{*}{$\begin{array}{c}\text { RMSE } \\
\text { (stations to DEM) [m } \\
11\end{array}$} \\
\hline 1 & $\left({ }^{\circ} \mathrm{C}\right)$ & & & & & & & & & & & & & \\
\hline 2 & $\left({ }^{\circ} \mathrm{C}\right)$ & -0.03 & 0.52 & 0.67 & - & - & - & 0.02 & 0.42 & 0.55 & - & - & - & 11 \\
\hline 3 & $\left({ }^{\circ} \mathrm{C}\right)$ & -0.06 & 0.43 & 0.53 & - & - & - & 0.00 & 0.37 & 0.47 & - & - & - & 11 \\
\hline 4 & (d) & -0.6 & 5.2 & 6.4 & $-1.7 \%$ & $17.0 \%$ & $20.4 \%$ & 0.1 & 4.0 & 6.3 & $2.4 \%$ & $12.3 \%$ & $16.0 \%$ & 52 \\
\hline 5 & (d) & 2.6 & 8.0 & 9.9 & $2.8 \%$ & $6.9 \%$ & $8.7 \%$ & 0.6 & 9.4 & 11.8 & $0.6 \%$ & $7.5 \%$ & $9.2 \%$ & 52 \\
\hline 6 & (d) & - & - & - & - & - & - & 0.4 & 9.0 & 11.5 & $1.4 \%$ & $10.2 \%$ & $13.1 \%$ & 52 \\
\hline 7 & (d) & -0.8 & 6.0 & 7.8 & - & - & - & -0.6 & 5.1 & 6.7 & - & - & - & 52 \\
\hline 8 & (d) & -0.2 & 1.6 & 2.1 & - & - & - & 0.0 & 1.2 & 1.7 & - & - & - & 52 \\
\hline 9 & $\left({ }^{\circ} \mathrm{C}\right)$ & 30.3 & 61.7 & 70.9 & $0.8 \%$ & $1.6 \%$ & $1.8 \%$ & 15.7 & 124.7 & 170.9 & $0.5 \%$ & $3.0 \%$ & $3.8 \%$ & 53 \\
\hline 10 & $(\mathrm{~mm})$ & 2 & 81 & 121 & $1.1 \%$ & $6.7 \%$ & $9.2 \%$ & 4 & 81 & 120 & $1.3 \%$ & $6.7 \%$ & $9.1 \%$ & 71 \\
\hline 11 & $(\mathrm{~mm})$ & 1 & 42 & 64 & $1.9 \%$ & $9.1 \%$ & $12.4 \%$ & 3 & 43 & 63 & $2.4 \%$ & $9.2 \%$ & $12.3 \%$ & 71 \\
\hline & $(\mathrm{mm})$ & 1 & 44 & 65 & $0.8 \%$ & $5.9 \%$ & $8.1 \%$ & 1 & 43 & 65 & $0.8 \%$ & $5.9 \%$ & $8.0 \%$ & 71 \\
\hline 13 & (d) & -0.1 & 5.1 & 10.2 & $0.2 \%$ & $4.5 \%$ & $7.9 \%$ & -0.1 & 4.4 & 5.7 & $0.2 \%$ & $3.8 \%$ & $4.9 \%$ & 32 \\
\hline & $(\%)$ & 0.0 & 2.4 & 3.0 & $1.1 \%$ & $9.9 \%$ & $12.7 \%$ & 0.2 & 1.7 & 2.2 & $1.7 \%$ & $6.9 \%$ & $8.9 \%$ & 49 \\
\hline 15 & $(\mathrm{~cm})$ & 1 & 30 & 51 & $3.1 \%$ & $13.5 \%$ & $17.8 \%$ & 6 & 33 & 59 & $4.8 \%$ & $14.1 \%$ & $19.2 \%$ & 43 \\
\hline 16 & (d) & 0 & 6 & 8 & $1.4 \%$ & $7.7 \%$ & $10.3 \%$ & 1 & 6 & 9 & $1.8 \%$ & $7.9 \%$ & $10.8 \%$ & 43 \\
\hline & $(\mathrm{cm})$ & 0 & 8 & 13 & $2.7 \%$ & $12.8 \%$ & $17.1 \%$ & 1 & 7 & 12 & $3.8 \%$ & $12.9 \%$ & $16.9 \%$ & 43 \\
\hline
\end{tabular}

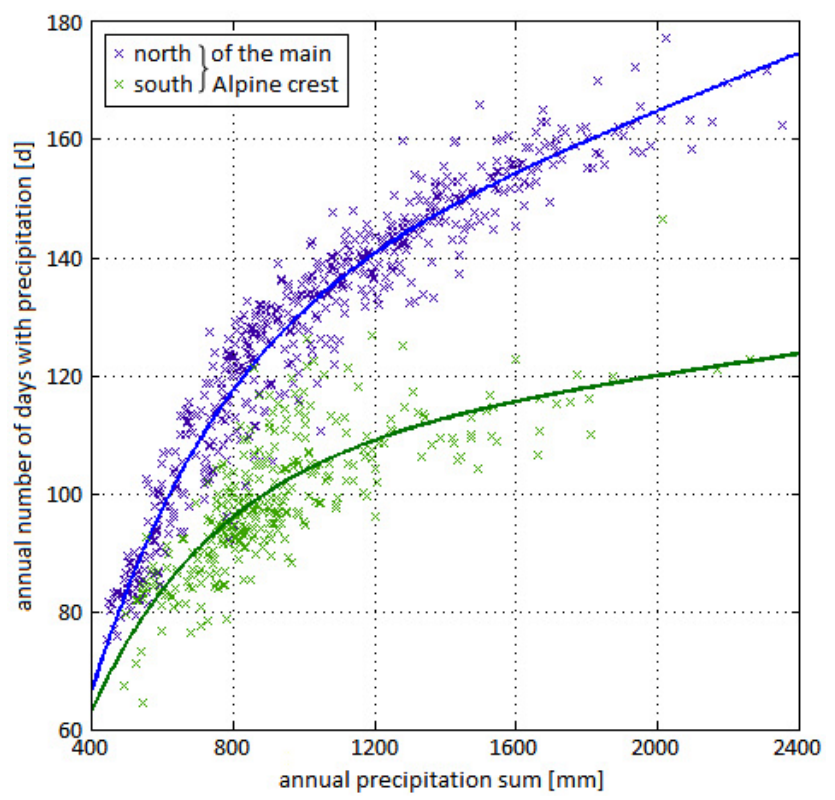

Figure 5. Exponential fitting of annual number of days with precipitation to annual precipitation sum over two subsets of Austrian station data, i.e. stations north and south of the main Alpine crest.

Curve fitting performed on secondary parameters of air temperature and precipitation leads to small additional systematic biases. The RMSRE values range widely between only $1.8 \%$ for the fitting of the number of heating degree days to air temperature and $20.4 \%$ for the fitting of the number of ice days to air temperature. That this measure of statistical dispersion does not necessarily go along with statistical correlation is shown by the fact that the correlation coefficient for the fitting of heating degree days is as high as 0.99 (cf. Table 2). As the annual number of summer days and hot days are parameters reaching values of zero in the study region, the calculation of relative error measures does not make sense and only the absolute errors are indicated.

The given error estimation has to be qualified by adding that station measurements as reference datasets are not holding climate reality but, to a certain degree, are biased themselves. Shifting measurement practices, station relocations, microclimatic superimpositions and all other kinds of inhomogeneities induce unwanted noise to the climate sign. Even if its fraction in the remaining error cannot be determined, seeking for a final error of zero is misleading in any case and cannot be the target of interpolation. Altogether, it can be concluded that the resulting error values are satisfactory as they are within the typical range of measurement insecurities.

A comparison to the preceding ÖKLIM maps of Auer et al. (2001) cannot be presented in terms of quantitative error reduction, as evaluation was not carried out then. However, extending the dataset by measurements from neighbouring countries has potentially improved interpolation performance in border-near regions, gap-filling incomplete time series has considerably increased spatial data coverage and applying an updated DEM has decreased elevation-caused errors. In addition, geographically weighted regressions, capable to capture higher spatial climate variability, had not been used before as well as mesoclimatic effects have been considered in more detail. For these reasons, an improvement in the quality of the new climate grid field appears very reasonable. 


\section{Results}

The 17 finished interpolation results are available either as digital grid fields or as cartographically prepared products. Examples of the results are shown in Figs. 2-4. The digital grids, which have been cut out to the Austrian national borders, are featured by a cell size of $200 \times 300 \mathrm{~m}$. As the result of a collateral project (Jurković et al., 2010), similar maps for Austria and the period 1971-2000 on monthly, seasonal and annual global radiation, absolute and relative sunshine duration can be obtained additionally.

For cartographic preparation, the mapping of each climate grid has been complemented by statistical measures, a histogram chart on the areal distribution of the depicted parameter and technical specifications (Fig. 4). For further information, contact details and a preview of all maps see the project web page (http://www.zamg.ac.at/forschung/ klimatologie/klimamodellierung/oeklim2).

\section{Conclusions}

The reissued collection of Austrian climate maps (ÖKLIM 1971-2000) suggests a quality improvement that has been achieved by several data and methodical adaptations: By including foreign observational data border effects towards data free regions were avoided. Spatial climate information could be increased by closing incomplete data series. Employing a new DEM helped capture the Eastern Alps' topography better. Accounting for the developments in interpolation methodology allowed for higher spatial variability and additional mesoclimatic effects were resolved by tailored techniques. The digital fields facilitate the spatial interpretation of features of temperature, precipitation and snow climate distribution over Austria. They offer extensive application for various scientific and planning purposes.

Acknowledgements. The project ÖKLIM 1971-2000 was funded by the Austrian Federal Ministry of Science and Research. The work considerably benefitted from data provision by the ZAMG's sister institutes in different countries. The authors expressly thank Viktor Weilguni (HZB), Gerhard Müller-Westermeier (DWD), Vít Květoň (CHMI), Zita Bihari (OMSZ), Ksenija Zaninović (DHMZ), Mojca Dolinar (ARSO), Stefano Micheletti (OSMER-ARPA), Günther Geier (Hydrographical Office, South Tyrol) and Christof Appenzeller (MeteoSwiss). Furthermore, the authors appreciate the constructive remarks of the two reviewers, which substantially improved the paper.

Edited by: M. Dolinar

Reviewed by: M. Maugeri and another anonymous referee

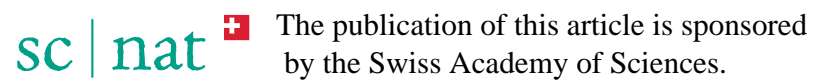

\section{References}

Auer, I., Böhm, R., Mohnl, H., Potzmann, R., Schöner, W., and Skomorowski, P.: ÖKLIM: digitaler Klimaatlas Österreichs, Zentralanstalt für Meteorologie und Geodynamik, Vienna, Austria, CD-ROM, 2001.

Auer, I., Matulla, C., Böhm, R., Ungersböck, M., Maugeri, M., Nanni, T., and Pastorelli, R.: Sensitivity of frost occurrence to temperature variability in the European Alps, Int. J. Climatol., 25, 1749-1766, 2005.

Auer, I., Böhm, R., Jurković, A., Lipa, W., Orlik, A., Potzmann, R., Schöner, W., Ungersböck, M., Matulla, C., Briffa, K., Jones, P. D., Efthymiadis, D., Brunetti, M., Nanni, T., Maugeri, M., Mercalli, L., Mestre, O., Moisselin, J. M., Begert, M., MüllerWestermeier, G., Květoň, V., Bochníček, O., Št'astný, P., Lapin, M., Szalai, S., Szentimrey, T., Cegnar, T., Dolinar, M., GajíćČapka, M., Zaninović, K., Majstorović, Z., and Nieplova, E.: HISTALP: Historical instrumental climatological surface time series of the greater Alpine region 1760-2003, Int J. Climatol., 27, 17-46, 2007.

Bénichou, P. and LeBreton, O.: Prise en compte de la topographie pour la cartographie de champs pluviométriques statistiques, La Météorologie, 7/19, 23-34, 1987.

BEV - Bundesamt für Eich- und Vermessungswesen: http://www. bev.gv.at/, last access: 9 December 2010.

Böhm, R.: Untersuchung des urbanen Einflusses auf das Niederschlagsfeld in der Umgebung einer Großstadt mit Hilfe verschiedener statistischer Methoden, Arch. Meteor. Geophy. B, 27, 225-246, 1979.

Carrega, P. (Ed.): Geographical information and climatology, ISTE, London, UK, 288 pp., 2010.

Cegnar, T. (Ed.): Climate of Slovenia, Hydrometeorological Institute of Slovenia, Ljubljana, Slovenia, 70 pp., 1995.

Daly, C., Neilson, R. P., and Phillips, D. L.: A statisticaltopographical model for mapping climatological precipitation over mountainous terrain, J. Appl. Meteorol., 33, 140-158, 1994.

Daly, C., Halbleib, M., Smith, J. I., Gibson, W. P., Doggett, M. K., Taylor, G. H., Curtis, J., Pasteris, P. P.: Physiographically sensitive mapping of climatological temperature and precipitation across the conterminous United States, Int. J. Climatol., 28, 2031-2064, 2008.

Dobesch, H., Dumolard, P., and Dyras, I. (Eds.): Spatial interpolation for climate data: the use of GIS in climatology and meteorology, ISTE, London, UK, 284 pp., 2007.

DWD (German Weather Service): Klimaatlas Bundesrepublik Deutschland: Teil 1, Deutscher Wetterdienst, Offenbach, Germany, CD-ROM, 1999.

Frei, C. and Schär, C.: A precipitation climatology of the Alps from high-resolution rain-gauge observations, Int. J. Climatol., 18, 873-900, 1998.

Hiebl, J., Auer, I., Böhm, R., Schöner, W., Maugeri, M., Lentini, G., Spinoni, J., Brunetti, M., Nanni, T., Perčec Tadić, M., Bihari, M., Dolinar, M., and Müller-Westermeier, G.: A highresolution 1961-1990 monthly temperature climatology for the greater Alpine region, Meteorol. Z., 18/5, 507-530, 2009.

Hutchinson M. F.: Interpolating mean rainfall using thin plate smoothing splines, Int. J. Geogr. Inf. Syst., 9/4, 385-403, 1995. 
Jurković, A., Türk, K., Orlik, A., Auer, I., Böhm, R., Potzmann, R., and Schöner, W.: SON-ALP: Interpolationen der Sonnenscheindauer sowie Globalstrahlung in Hinblick auf Klimaänderungen im Alpenraum, Zentralanstalt für Meteorologie und Geodynamik, Vienna, Austria, Internal technical report, 66 pp., 2010.

Klein, T. and Persson, C.: Showcase EUROGRID - towards a European resource for gridded climate data, products and services, Adv. Sci. Res., 3, 85-89, doi:10.5194/asr-3-85-2009, 2009.

Peterson, T. C., Easterling, D. R., Karl, T. R., Groisman, P., Nicholls, N., Plummer, N., Torok, S., Auer, I., Böhm, R., Gullett, D., Vincent, L., Heino, R., Tuomenvirta, H., Mestre, O., Szentimrey, T., Salinger, J., Førland, E. J., Hanssen-Bauer, I., Alexandersson, H., Jones, P., and Parker, D.: Homogeneity adjustments of in situ atmospheric climate data: a review, Int. J. Climatol., 18, 1493-1517, 1998.
Schwarb, M.: The Alpine precipitation climate: evaluation of a high-resolution analysis scheme using comprehensive rain-gauge data, Swiss Federal Institute of Technology, Zürich, Switzerland, Dissertation 13911, 131 pp., 2000.

Zaninović, K., Gajíć-Čapka, M., and Perčec Tadić, M.: Klimatski atlas Hrvatske: climate atlas of Croatia 1961-1990, 1971-2000, Meteorological and Hydrological Service of Croatia, Zagreb, Croatia, 200 pp., 2008. 